\title{
ĐÁNH GIÁ VIỂC TRIỂN KHAI THỰC HIỆN THANH TOÁN XÉT NGHIỆM TẢ̉ LƯỢNG VIRUS TỪ NGUỒN BẢO HIỂM Y TẾ
}

\section{TÓM TẮT}

Xét nghiệm tải lượng virus HIV là một xét nghiệm quan trọng trong theo dõi, điều trị HIV/AIDS. Nghiên cứu này được thực hiện nhằm tìm hiểu quá trình chuyển đổi sang phương thức chi trả từ BHYT cho xét nghiệm tải lượng virus và đưa ra các khuyến nghị cần thiết để đảm bảo hiệu quả và tính bền vững trong công tác phòng chống HIV/AIDS. Nghiên cứu áp dụng thiết kế kết hợp, với số liêu định lượng từ báo cáo thứ cấp và số liệu định tính từ phỏng vân sâu các cán bộ liên quan từ tuyên Trung Ương đến đia phương. Mấu nghiên cứu được lựa chọn trong các tỉnh của dự án PEPFAR. Kết quả nghiên cứu cho thấy quá trình chuyển đổi sang thanh toán từ nguồn BHYT cho điều tri HIV/AIDS nói chung và xét nghiêm tải lượng virus nói riêng được thực hiện thuận lợi, không có tác động tiêu cực đến công tác điều trị bệnh nhân HIV/AIDS tại Việt Nam. Nghiên cứu chỉ ra được các khó khăn/ rào cản khi thực hiện chi trả xét nghiệm từ nguồn BHYT như độ phức tạp của thủ tục chi trả, hạn chế của hệ thống thông tin, thiếu một số quy định về duy trì quyền lợi BHYT cho người bệnh. Các kết quả của nghiên cứu có thể được sử dụng vào việc sửa đổi các quy định chính sách hiện hành để đảm bảo tối đa quyền lơi của bênh nhân HIV/AIDS tai Viêt Nam

Từ khóa: HIV/AIDS, tải lượng virus, Bảo hiểm Y tế

\section{SUMMARY}

\section{ASSESSMENT OF THE IMMPLEMENTATION OF PAYMENT FOR VIRAL LOAD TEST FROM HEALTH INSURANCE IN VIETNAM}

HIV viral load test is an important test in HIV / AIDS monitoring and treatment. This study was conducted to understand the transition to health insurance payment for viral load testing and to provide necessary recommendations to ensure effectiveness and sustainability in HIV/AIDS prevention. AIDS. The study applied a mixed design, with quantitative data from the secondary report and qualitative data from in-depth interviews with relevant officials from the central government to the local government. Study samples were selected in the provinces of the PEPFAR project. Research results show that the transition to payment from health insurance for HIV / AIDS treatment in general and viral load in particular has been carried out smoothly, with no negative effects on the treatment of the disease. HIV / AIDS in Vietnam. The study pointed out

*Trường Đại học Y tế công cộng

Chịu trách nhiệm chính: Vũ Thị Hoàng Lan

Email:Vhl@huph.edu.vn

Ngày nhận bài: 8.3.2021

Ngày phản biên khoa học: 27.4.2021

Ngày duyệt bài: 7.5.2021

\section{Vũ Thị Hoàng Lan*, Bùi Tú Quyên*}

the difficulties / barriers to payment for testing from health insurance sources such as complexity of payment procedures, limitations of the information system, and lack of regulations on maintaining health insurance benefits for some special cases. The results of the study can be used to revise existing policies to maximize the rights of HIV / AIDS patients in Vietnam.

Keywords: HIV/AIDS, Viral load test, Health insurance

\section{I. ĐĂT VẤN ĐỀ}

Xét nghiệm tải lượng virus HIV đo lường lượng RNA của HIV trong một đớn vị thể tích (ml) huyết tương của người nhiễm HIV, xét nghiệm này dùng đánh giá tiến trình cũng như kết quả điều trị của bệnh. Tải lượng virus cao cho thấy nguy cơ lây nhiễm HIV cao, hoặc việc điêu trị HIV chưa có hiệu quả. Nếu kế hoạch điều trị HIV có tác dụng, bệnh nhân sẽ có tải lượng virus thấp, cũng giảm nguy cơ lây truyền HIV cho bạn tình của họ. Bộ Y tế đã có quyết định Số 1112/QĐ-BYT quy định về hướng dẫn thực hiện xét nghiệm tải lượng HIV trong theo dõi, điều trị HIV/AIDS (1). Mồ hình triển khai xét nghiệm tải lượng virus được dự án PEPFAR hỗ trợ là một mồ hình thành công, được thế giới công nhận. Việt Nam đang ở thời kỳ chuyển đổi từ việc dựa vào các nguồn kinh phí hỗ trợ từ quốc tế cho các hoạt động phòng chống HIV/AIDs sang việc sử dụng ngân sách nội địa. Chính phủ Việt Nam đã đưa ra các cam kết đề đảm bảo ổn đinh tài chính cho người nhiễm HIV/AIDS. Để tăng cường sử dụng quỹ bảo hiểm y tế để kiểm soát HIV/AIDS, năm 2016, Thủ tướng Chính phủ đã ban hành Quyết định số 2188 (2) về mua sắm thuốc ở cấp quốc gia, sử dụng quỹ Bảo hiểm y tế xã hội và hỗ trợ thuốc ARV cho HIV/AIDS người bệnh. Gần đây, Thông tư số $27 / 2018 /$ TT-BYT (3) ban hành ngày 26 tháng 10 năm 2018 về hướng dẫn thực hiện bảo hiểm y tế và khám bệnh, chữa bệnh BHYT liên quan đến HIV/AIDS.

Từ tháng $9 / 2019$, việc sử dung nguồn vốn BHYT chi trả cho thuốc ARV và xét nghiệm trong điêu trị đã bắt đầu được tiến hành tại các cơ sở y tế với dự kiến toàn bộ kinh phí cho các hoạt động này sẽ được hỗ trợ từ nguồn BHYT. Chi trả cho xét nghiệm tải lượng virus cũng đang trong quá trình chuyển đổi từ nguồn chi trả dự án hổ trợ sang nguồn chi trả từ BHYT và quá trình 
chuyển đổi sẽ gặp phải những khó khăn và thách thức nhất định. Nghiên cứu này được thực hiện nhằm tìm hiểu quá trình chuyển đổi sang phương thức chi trả từ BHYT cho xét nghiệm tải lượng virus và đưa ra các khuyến nghị cần thiết để đảm bảo hiệu quả và tính bền vững trong công tác phòng chống HIV/AIDS.

\section{II. ĐỐl TƯƠNG VÀ PHƯƠNG PHÁP NGHIÊN CỨU}

2.1 Thiết kế, thời gian và địa điểm nghiên cứu. Nghiên cứu cắt ngang kết hợp định lượng và định tính thực hiện từ tháng 7 đển tháng $9 / 2020$. Nghiên cứu định lượng thu thập số liệu tại 11 tỉnh của PEPFAR. Nghiên cứu định tính thực hiện tại tuyến trung ương (VAAC, NIHE, Pasteur TP Hồ Chí Minh) và 5 tỉnh bao gồm: Hà Nội, Hải Phòng, Thành phố Hồ Chí Minh, Thái Nguyên và Bà Rịa - Vũng Tàu. Các tỉnh được chọn có chủ đích: Miền Nam và Miền Bắc, có tỉnh chưa thực hiện thanh toán xét nghiệm tải lượng virus qua BHYT một cách hoàn chỉnh, có tỉnh đã thực hiện.

\section{2 Đối tượng và thông tin thu thập}

- Tuyến trung ương: (1) Lãnh đạo và các cán bộ liên quan của Cục PC HIV/AIDS; (2) Lãnh đạo và các cán bộ liên quan của Bảo hiểm xã hội Việt Nam; (3) Đại diện của NIHE và các viện Pasteur khu vực

- Tuyến tỉnh/ thành phố: (1) Lãnh đạo và cán bộ liên quan của Sở $Y$ tế, Trung tâm PC HIV/AIDS/Trung tâm Kiểm soát bệnh tật của tỉnh, cơ quan Bảo hiểm xã hội tỉnh, (2) Lãnh đạo và cán bộ liên quan của các cơ sở y tế đang thực hiện điều trị ARV; (3) Cơ sở cung cấp xét nghiệm tải lượng virus.

Các thong tin chính được thu thập trong nghiên cứu bao gồm (1) Thực trạng triển khai xét nghiệm tải lượng virus từ nguiôn BHYT; (2) Hệ thống thông tin quản lý tình trạng tham gia bảo hiểm y tế tại các cơ sở điều trị HIV/AIDS, hỗ trợ thanh toán chi phí xét nghiệm tải lượng virus; (3) Sự phối hợp giữa các cớ quan trung ương trong quá trình quản lý việc thanh toán xét nghiệm tải lượng virus từ nguồn bảo hiểm; (4) Phân tích các thuận lợi khó khăn trong việc thanh toan xét nghiệm tải lượng virus từ nguồn BHYT từ các bên liên quan

2.3 Phân tích số liệu. Số liệu khảo sát bằng phiếu thu thập số liệu thứ cấp: nhập số liệu bằng phần mềm Excel để phân tích theo các chỉ số đã xác định. Số liệu định tính: Gõ băng và phân tích theo phương pháp mã mở có chủ đề. Trích dẫn có chọn lọc đáp ứng mục tiêu nghiên cứu.

\section{KẾT QUẢ NGHIÊN CỨU VÀ BÀN LUẬN}

Cơ sở điêuu trị ARV và nguồn tài chính. Đến tháng $12 / 2019$, số cơ sở điêu trị hoàn thành kiện toàn đáp ứng các điều kiện khám chữa bệnh HIV/AIDS qua quỹ Bảo hiểm y tế là $395 / 431$ (91\%), trong đó 362/395 (91,2\%) cơ sở điêu trị thực hiện thanh toán dịch vụ khám chữa bệnh Bảo hiểm y tế. Hiệ̂n có 25/63 tỉnh, thành phố đảm bảo kinh phí hố trợ đồng chi trá thuốc ARV cho điều trị người nhiễm HIV với tổng kinh phí được phê duyệt là trên 21,1 tỷ đồng; tổng kinh phí đã hố trợ đồng chi trả đến 31/10/2019 là trên 1,9 tỷ đồng.

Bảng 1: Số lượng cớ sở điều trị ARV theo nguồn cung cấp thuốc năm 2019

\begin{tabular}{|c|c|c|}
\hline Nội dung & $\begin{array}{c}\text { Số } \\
\text { Iượng } \\
\text { Cớ sở }\end{array}$ & $\begin{array}{c}\text { Số lượng } \\
\text { bệnh } \\
\text { nhân } \\
\text { ARV }\end{array}$ \\
\hline Nguồn ngân sách nhà nước & 124 & 16.244 \\
\hline Nguồn từ quỹ toàn cầu & 170 & 46.057 \\
\hline $\begin{array}{c}\text { Nguồn từ chương trình } \\
\text { PEPFAR }\end{array}$ & 76 & 38.620 \\
\hline Nguồn bảo hiếm y tế & 188 & 38.356 \\
\hline
\end{tabular}

*Ngân sách nhà nước: Đây là nguồn từ Dự án 5 của Chương trình mục tiêu $Y$ tế - Dân số giai đoạn 2016-2020 bao gồm các cơ sở điều trị ARV đặc thù được nhận kinh phí/thuốc hoàn toàn từ nguồn NSNN; các cơ sở điêu trị ARV đặt tại các tỉnh không có nguồn viện trợ; các cơ sở điều trị ARV không ký hợp đồng bảo hiểm y tế nên sẽ có cả cơ sở BHYT được liệt kê trong số lượng hưởng nguồn NSNN.

Bảng 1 mô tả các cơ sở điều trị ARV theo nguồn cung cấp thuốc năm 2019 (Biểu mẫu thu thập số liệu tại Cục Phòng, chống HIV/AIDS năm 2019). Hiện nay, có 188 cơ sở nhận thuốc từ nguồn BHYT, 170 cơ sở nhận thuốc từ Quỹ toàn cầu, 76 cơ sở nhận thuốc từ chương trình PEPFAR. Nguồn ngân sách nhà nước bao gồm các cơ sở điều trị ARV đặc thù được nhận kinh phí/thuốc hoàn toàn từ NSNN; các cơ sở điều trị ARV đặt tại các tỉnh không có nguồn viện trợ; và các cơ sở điều trị ARV không ký hợp đồng bảo hiểm y tế. Vì vậy, trong 124 cơ sở nhận thuốc nguồn NSNN, sẽ có cả các cơ sở có thuốc từ nguồn BHYT.

Bao phủ bảo hiểm y tế cho người nhiễm HIV

Theo số liệu thống kê của Cục Phòng, chống HIV/AIDS, tỷ lệ bao phủ BHYT trong bệnh nhân HIV/AIDS của Việt Nam tăng lên rõ rệt trong những năm qua kể từ sau khi có Quyết định 2188 của Thủ tướng Chính phủ (2). Cụ thể, 
trước tháng 10/2016 (trước khi ban hành $\mathrm{QĐ}$ 2188 ) chỉ có $50 \%$ bệnh nhân HIV/AIDS có thẻ BHYT, nhưng đến năm 2017 tăng lên là $82 \%$, tháng $31 / 10 / 2018$ tăng lên $89 \%$, đến hết tháng 9/2019 đã tăng đến $91 \%$. Trong đó có 9 tỉnh có tỷ lệ bao phủ đạt $100 \%$ (Tuyên Quang, Kon Tum, Bình Định, Hà Giang, Đà Nẵng, Sóc Trăng, Quảng Ngãi, Quảng Trị, Hưng Yên); có 40/63 tỉnh, thành phố trực thuộc Trung ương đã bố trí ngân sách địa phương mua 16.069 thẻ Bảo hiểm y tế cho người có HIV với tổng kinh phí hơn 13 tỷ đồng.

Thuận lợi khó khăn trong triển khai xét nghiệm tải lượng virus từ nguồn $\mathrm{BHYT}$

Trong quá trình triển khai xét nghiệm tải lượng virus HIV, các địa phương có một số thuận lợi và cũng gặp một số khó khăn như sau:

\section{(a) Thuận lợi}

$\checkmark$ Sự chỉ đạo quyết liệt của Chính Phủ và vai trò chủ động, tích cực của Bộ $Y$ tế, Cục phòng chống HIV/AIDS và BHXH Việt Nam thông qua các Nghị định, Thông tư, Hướng dẫn được ban hành trong thời gian qua. Mới nhất là Chiến lược Quốc gia Chấm dứt dịch bệnh AIDS vào năm 2030 (QĐ 1246/QĐ-TTg) (4) với mục tiêu tỷ lê người nhiễm HIV điều trị thuốc kháng virus HIV có tải lượng virus dưới ngưỡng ức chế được nâng lên $95 \%$ và $100 \%$ người nhiễm HIV tham gia BHYT. Đây là cơ sở để các địa phương, cơ sở điều trị... có những hoạt động phù hợp nhằm đạt được các mục tiêu này trong giai đoạn tiếp theo.

$\checkmark$ Yếu tố quan trọng quyết định trong triển khai thực hiện chính sách đó là đạt được sự đồng thuận chính trị cao của các cấp chính quyền từ Trung ương đến địa phương, từ Hội đồng nhân dân, Uỷ ban nhân dân, Sở $Y$ tế đến các Đơn vị trực thuộc Sở $Y$ tế và cơ quan $B H X H$. Sau khi có Công văn của Cục phòng chống HIV/AIDS về việc cung cấp xét nghiệm trong chẩn đoán và theo dõi điều trị HIV qua BHYT (Công văn số 21/AIDS-ĐT ngày 09/01/2018) (5), Sở y tế các tỉnh/ thành phố đã ra các văn bản chỉ đạo các cơ sở điều trị cho bệnh nhân HIV/AIDS thực hiện công văn này.

$\checkmark$ Sự phối hợp chặt chẽ và hiệu quả giữa Bộ $Y$ tế - Cục phòng chống HIV/AIDS và cơ quan BHXH Việt Nam từ ban hành văn bản đến hướng dẫn thực hiện và theo dõi giám sát quá trình triển khai tại các địa phương để kịp thời tháo gõ vướng mắc.

$\checkmark$ Huy động được nguồn lực từ các nguồn khác nhau từ nguồn hố trợ trong nước và quốc tế cho việc mua thẻ BHYT cho bệnh nhân HIV/AIDS. $\checkmark$ Điều phối và sử dụng hiệu quả nguồn tài trợ quốc tế trong mua thẻ BHYT cho người nhiễm HIV.

$\checkmark$ Hầu hết các cơ sở điều trị ngoại trú cho bệnh nhân HIV (OPCs) đều đã thực hiện thanh toán thuốc $A R V$ qua BHYT trước đó nên cũng đã có kinh nghiệm trong thực hiện các thanh quyết toán qua BHYT cũng như đã có đủ điều kiện về con người, cơ sở vật chất để đáp ứng yêu cầu của BHYT trong triển khai thanh toán xét nghiệm tải lượng virus qua BHYT.

$\checkmark$ Việc thực hiện xét nghiệm tải lượng virus thanh toán từ nguiôn BHYT có nhiều điểm đặc thù, theo phương thức và cơ chế khác biệt so với các quy định đang vận hành trong thanh toán BHYT nói chung. Bộ Y tế ban hành văn bản hướng dẫn đầy đủ, kịp thời đồng thời tổ chức tập huấn trên toàn quốc đến tất cả các Sở Y tế, cơ sở điều trị nắm bắt văn bản để thực hiện.

$\checkmark$ Điều kiện quan trọng nhất để các đơn vị phối hợp tốt là có quy chế và thiết lập hệ thống kết nối, chia sẻ thông tin về quản lý bệnh nhân HIV, cung ứng vật tư tiêu hao, thực hiện các xét nghiệm, chi phí cho xét nghiệm và đồng chi trả cho xét nghiệm cũng như và chi phí hỗ trợ bệnh nhân HIV.

\section{(b) Khó khăn}

\section{Khó khăn từ hê thống y tề}

$\checkmark$ Thiếu hướng dẫn kịp thời khi xử lý các vấn đề phát sinh như vấn đề mua thẻ BHYT cho đối tượng không phải là người địa phương đang sinh sống trên địa bàn, biểu mẫu báo cáo chưa cập nhật, đồng bộ.

$\checkmark$ Hệ thổng thông tin chưa đáp ứng được yêu câu quản lý:

- Chưa có ứng dụng phần mềm quản lý bệnh nhân HIV toàn quốc, kết nối giữa thông tin quản lý bệnh nhân và quản lý thẻ BHYT cho phép cập nhật liên tục tình hình thực hiện chính sách bao gồm cả việc cấp thẻ BHYT, sử dụng thẻ BHYT và chi phí phát sinh khi sử dụng thẻ.

- Phần mềm quản lý KCB chưa đồng bộ, kết nối quản lý bệnh nhân và thanh toán BHYT

$\checkmark$ Chưa có qui định cụ thể về thời gian giám định và thông báo kết quả về thanh quyết toán xét nghiệm tải lượng virus BHYT.

$\checkmark$ Việc phối hợp giữa các bên trong giải quyết vướng mắc, vấn đề phát sinh còn chậm trễ: chậm thông tin về khả năng thực hiện xét nghiệm (Thái Nguyên), phản hồi vướng mắc từ cơ sở.

Từ phía cơ sở y tế địa phương

Vướng mắc chung trong việc triển khai BHYT tại các cơ sở 
$\checkmark$ Hiểu biết về các văn bản hướng dẫn còn han chế: Trên thực tế, vẫn còn tình trạng chưa nẳm vững quy định đặc biệt là quy định về hỗ trợ đồng chi trả xét nghiệm $V L$, quy định về chế độ thanh toán $\mathrm{BHYT}$, qui định về thời gian trả kết quả xét nghiệm...

$\checkmark$ Một số cơ sở vốn làm công tác dự phòng như TTYT dự phòng, CDC không có kinh nghiệm trong KCB BHYT nên khi thực hiên công tác điều trị cho bệnh nhân HIV, gặp vướng mắc trong thực hiện các quy định thanh toán BHYT.

$\checkmark$ Chưa có kinh nghiệm thanh toán BHYT nên khá lúng túng: Phòng khám ngoai trú của CDC các tỉnh; PK ngoại trú của TTYT huyện chỉ thực hiện chức năng dự phòng, nhiều nơi chưa thể/ chưa đủ điều kiện ký hợp đồng thực hiện xét nghiệm VL thanh toán qua BHYT.

$\checkmark$ Còn tồn tại song song nguồn dự án và nguồn BHYT nên quản lý bệnh nhân chồng chéo, không quyết liệt giải quyết các vướng mắc khi thực hiên xét nghiêm VL qua BHYT: theo dõi, nắm bắt, cập nhật tình hình triển khai chưa kịp thời, chính xác. Nhiều cơ sở còn ngại thực hiện qua BHYT nên triển khai còn dè dặt, thậm chí là né tránh chỉ định thanh toán qua BHYT mà vẫn dựa vào nguồn dự án.

Vướng mắc với xét nghiệm tải lượng virus

$\checkmark$ Các đơn vị phải chuyển gửi xét nghiệm, việc trả kết quả có thể bi châm do các lý do: Hết sinh phẩm, đơn vị tiến hành xét nghiệm bị quá tải.

$\checkmark$ Chưa có cơ chế để quy trách nhiệm rõ ràng các bên trong việc chậm gửi trả kết quả xét nghiệm. Ví dụ: với BVĐKTƯ Thái Nguyên, hết sinh phẩm và không thể nhập được trong một khoảng thời gian dài do ảnh hưởng của dịch COVID-19 nên gần 1 tháng vẫn không thể thực hiên được các xét nghiệm được OPCs chuyển đển, tuy nhiên trong hợp đồng giữa hai bên (OPC và đơn vị làm xét nghiệm) không có điều khoản qui định cho sự chậm trễ trong trả kết quả này.

$\checkmark$ Hỏng mẫu: Bảo hiểm quy định chỉ chi trả một lần cho các chỉ định xét nghiệm được thực hiện theo đúng Hướng dẫn theo dõi, điều trị bểnh nhân HIV, nếu hỏng mẫu cơ sở điều trị phải chỉ định phải làm lại cho bệnh nhân, chi phí này sẽ khồng được BHYT chi trả.

$\checkmark$ Bảo hiểm quy định thời gian xét nghiệm cho các bệnh nhân chặt hơn dự án, có những bệnh nhân do đi công tác, công việc cá nhân xét nghiệm chậm hơn so với lịch có thể sẽ không được chấp nhận do không đúng theo Hướng dẫn của Bô y tế.

$\checkmark$ Cần có hướng xử lý với các trường hợp hết hạn, gia hạn thẻ để đảm bảo cho quyền lợi bệnh nhân: Bệnh nhân đang ở thời kỳ chuyển giao giữa thẻ cũ, thẻ mới (thẻ mới cần 30 ngày mới có thể thực hiện thanh toán) $\rightarrow$ nếu làm xét nghiệm vào thời điểm này sẽ không chỉ định được qua BHYT.

\section{Từ phía co quan BHXH}

$\checkmark$ Chưa thực hiện giám định hoặc chưa có kết quả giám định để chốt số quyết toán quý 1 , quý 2 cho các CSYT (tính đến thời điểm khảo sát ở cả 4 tỉnh)

$\checkmark$ CSYT chậm nộp báo cáo tổng hợp chi phí đề nghị quyết toán Q1+Q2 (1 số cơ sở y tế)

Từ phía bệnh nhân

$\checkmark$ Chưa hiểu biết đầy đủ về chế độ BHYT: Chưa tích cực tham gia BHYT, chưa phát huy quyền của mình trong giám sát việc thực hiện của cơ sở y tế và cơ quan $\mathrm{BHXH}$.

$\checkmark$ Tâm lý e ngại bị kỳ thị đối xử: Không dùng thẻ BHYT, không kê khai nhận hố trợ mua thẻ do lo sơ thông tin cá nhân bi lộ.

$\checkmark$ Không có giấy tờ tùy thần dẫn đến vướng mắc trong mua thẻ, vướng mắc trong thủ tục KCB: Một số bệnh nhân HIV không có giấy tờ tùy thân (phạm nhân vừa ra tù...) dẫn đến không đủ điều kiện để mua thẻ BHYT.

$\checkmark$ Không tuân thủ đầy đủ các quy định KCB BHYT.

\section{KẾT LUÂN}

Nghiên cứu mô tả thực trạng triển khai chi trả xét nghiệm tải lượng virus, một xét nghiệm quan trọng trong theo dõi, điêu trị HIV/AIDS trong bối cảnh chuyển đổi từ chi trả xét nghiệm từ nguồn nhà tài trợ sang BHYT. Kết quả nghiên cứu cho thấy quá trình chuyển đổi sang thanh toán từ nguî̀n BHYT cho điêuu trị HIV/AIDS nói chung và xét nghiệm tải lượng virus nói riêng được thực hiện thuận lợi, không có tác động tiêu cực đển công tác điêuu trị bệnh nhân HIV/AIDS tại Việt Nam. Các yếu tố tạo điều kiện thuận lợi cho thành công này bao gồm Sự chỉ đạo quyết liệt của Chính Phủ và vai trò chủ động, tích cực của Bộ Y tế, Cục phòng chống HIV/AIDS và BHXH Việt Nam; Sự phối hợp chặt chẽ và hiệu quả giữa Bộ Y tế - Cục phòng chống HIV/AIDS và cơ quan BHXH Việt Nam; Sự sẵn có và đầy đủ của các văn bản pháp luật hướng dẫn, chỉ đạo quá trình thanh toán. Một số khó khăn cần khắc phục bao gồm Hệ thống thông tin chưa đáp ứng được yêu cầu quản lý; cán bộ y tế còn lúng túng với các thủ tục thanh toán, thủ tục và thời gian xử lý hồ sơ cho xét nghiệm từ nguiồn BHYT phức tạp hơn so với từ nguồn tài trợ; cần có các quy định hỗ 
trơ trường hợp hết han, gia hạn thẻ BHYT để đảm bảo cho quyền lợi bệnh nhân HIV/AIDS đang trong quá trình điều trị.

\section{TÀI LIÊU THAM KHẢO}

1. Bộ Y tế. Quyết định 1112/QĐ-BYT 2019 Hướng dấn thức hiên xét nghiêm tải lượng HIV. Bộ Y tế; 2019 [Ngày truy cập 16/2/2021]. Truy cập tai: https://luatvietnam.vn/y-te/quyet-dinh-1112qd-byt-2019-huong-dan-thuc-hien-xet-nghiem-tailuong-hiv-171584-d1.html

2. Thủ tướng Chính phủ. Quyết định $2188 / \mathrm{Q} Đ-T T g$ thanh toán thuốc kháng virút HIV mua săm tập trung cấp quốc gia 2016. Văn phòng Thủ tướng; 2016 [Ngày truy cập: 16/2/2021]. Truy cập tại: https://thuvienphapluat.vn/van-ban/Baohiem/Quyet-dinh-2188-QD-TTg-thanh-toan-thuockhang-virut-HIV-mua-sam-tap-trung-cap-quoc-gia2016-329879.aspx

3. Bộ Y tế. Thông tư $27 / T T-B Y T$ ngày $26 / 10 / 2018$ về
Hướng dẫn thực hiện bảo hiểm y tế và khám bệnh, chữa bênh bảo hiểm y tế liên quan đến HIV/AİDS. Bộ Y tế; 2018 [Ngày truy cập 16/2/2021]. Truy cập tại: http:// vaac.gov.vn/ vanban detail/ Detail/ Thong-tu-27-TT-BYT-ngay-26-10-2018-ve-Huongdan-thuc-hien-bao-hiem-y-te-va-kham-benh-chuabenh-bao-hiem-y-te-lien-quan-den-HIV-AIDS

4. Thư tướng Chính phủ. Chiến lược Quốc gia chấm dứt dịch bênh AIDS vào năm 2030. Văn phòng Thủ tướng; 2020 [ngày truy cập 19/2/2021]. Truy cập tại: http:// vaac.gov.vn/ vanban detail/Detail/Chien-luoc-Ouoc-qia-chamdut-dich-benh-AIDS-vao-nam-2030

5. Bố Y tế. Công văn 21/AIDS-ĐT cung cấp xét nghiệm trong chẩn đoán và theo dõi điêuu trị HIV qua BHYT. Cục phòng chống HIV/AIDS; 2018 [ngày truy câp 20/2/2021]. Truy câp tai: https://vnras.com/cong-van-21-aids-dt-cung-capxet-nghiem-trong-chan-doan-va-theo-doi-dieu-trihiv-qua-bhyt/

\section{DỊCH TỄ HỌC TRẺ EM ĐIỀU TRI NộI TRÚ TẠI BÊNNH VIÊ̂N ĐA KHOA TỈNH HÀ TĨNH GIAI ĐOÂN 2011-2019}

\section{Hoàng Quang Trung*, Dương Văn Giáp*, Trương Huy Hưng*, Đặng Quang Minh*, Nguyễn Thị Liên*, Trần Thị Hương*, Nguyễn Đình Phi*, Cao Thế Vinh* và cộng sự \\ nhập viện tại bệnh viện đa khoa Hà tĩnh tương tự tại một số tỉnh trong nước. \\ Tư khóa: trẻ em, dịch tễ học \\ SUMMARY \\ EPIDERMIOLOGY OF CHILDREN TREATED \\ AT THE HATINH GENERAL HOSPITAL FROM 2011 TO 2019}

\section{TÓM TẮT}

Mô hình bệnh tật của một quốc gia, một cộng đồng phản ánh tình hình sức khỏe, tình hình kinh tế xã hội của quốc gia hay cộng đồng đó. Nghiên cứu mô hình bệnh tật của một khoa, một bệnh viện có ý nghĩa thiết thực trong công tác tổ chức y tế, xây dựng kế hoach chăm sóc sức khỏe, điều trị dư phòng phù hợp. Đồng thời giúp xây dựng kế hoạch huấn luyện, đào tao và nghiên cứu khoa hoc cho bệnh viên đó. Hà tĩnh là tỉnh thuộc miên Trung Việt nam, tỷ lệ trẻ nhập viện điều tri nôi trú còn cao. Muc tiêu: Khảo sát môt số yếu tố dịch tễ trẻ em điều trị nội trú tại Bệnh viện Đa khoa tỉnh Hà Tĩnh giai đoạn 2011-2019. Đối tướng nghiên cứu: Gồm 46.798 trẻ em điều trị nội trú tại Bệnh viện Đa khoa tỉnh Hà tĩnh từ 01/2011 đển 04/2019. Phương pháp nghiên cứu: Nghiên cứu hồi cứu, mô tả cắt ngang. Kết quả: Tổng số bệnh nhân nhi vào viện điều trị nội trú chiếm $13,65 \%$ so với bênh nhân toàn viên; bệnh nhân nhi tăng từ 2.877 bệnh nhân (2011) lên 9.917 bệnh nhân (2018); trẻ nam là $61,25 \%$. Trẻ $\leq 5$ tuổi chiếm $73,86 \%$. Trẻ sống ở nông thôn chiếm $67,75 \%$. Bệnh nhân nhập viện đều trong năm, tháng giao mùa $3,4,5$ và 8,9 , 10 nhập viện nhiều hơn. Kết luận: Đặc điểm dịch tễ học trẻ em

*Bênh viên Đa khoa tỉnh Hà Tïnh

Chịu trách nhiệm chính: Dương Văn Giáp

Email: drgiap9@gmail.com

Ngày nhận bài: 4.3.2021

Ngày phản biên khoa học: 26.4.2021

Ngày duyệt bài: 7.5.2021
Patterns of morbidity and mortality of a nation or a population reflect health and economy status. Investigation the disease's pattern contributes to build up the health system, to plan appropriate health care service, training, and health's education. Hatinh is a Central province of Vietnam, where the prevalance of inpatient children is still high. Objectives: To assess the children's epidemiological factors who was treated at the Hatinh General hospital from 2011 to 2019. Study subjects and methods: There was of 46.798 children who were treated at the hospital from January, 2011 to April, 2019. This was a retrospective study. Results: Children who were treated at the hospital accounting for $13,65 \%$ of total inpatients; the number of inpatients was increased from 2.877 in 2011 to 9.917 in 2018; in which male was $61,25 \%$. Patients under 5 year old was $73,86 \%$. The number of patients admitted to hospital was increased in weather changing periods such as March, April, May and August, September and October. Conclusion: The epidermiological features of children treated at the Hatinh General Hospital is similar other hospitals.

Keywords; children, epidermiology. 